\title{
ANALISIS PENENTUAN HARGA POKOK PRODUKSI MENGGUNAKAN METODE FULL COSTING SEBAGAI DASAR PENETAPAN HARGA JUAL PADA UD. MUTIA MEUBEL
}

\begin{abstract}
Sri Hartatik
${ }^{1}$ Politeknik Saint Paul Sorong Jl. R. A. Kartini No. 1 Kampung Baru, Sorong. Indonesia

ABSTRAK

Penelitian ini dilakukan untuk menganalisis harga pokok produksi sebagai dasar penetapan harga jual pada UD. Mutia Meubel dengan menggunaka metode full costing. UD. Mutia Meubel memperhitungkan harga pokok lemari selama sebulan, perusahaan selama ini hanya membebankan biaya bahan baku, biaya tenaga kerja dan belum membebankan biaya listrik, biaya telepon dan biaya depresiasi sebagai biaya overhead pabrik. Sedangkan pada prinsip akuntansi biaya untuk menghitung harga pokok produk menggunakan metode harga pokok pesanan; Terdapat perbedaan perhitungan harga pokok produksi antara UD. Mutia Meubel dengan penulis yang menggunakan metode full costing, yaitu harga pokok produksi lemari pakaian 2 pintu menurut perusahaan sebesar Rp 4.075.000,- dan Rp 3.470.000,- untuk produk rak buku. Sedangkan harga pokok produksi lemari pakaian 2 pintu menurut penulis sebesar $R p$ 4.226.310,- dan $R p$ 3.338.280,- untuk produk rak buku. Selisih harga pokok ini disebabkan adanya perbedaan perhitungan biaya overhead pabrik, seperti biaya listrik, biaya telepon dan biaya depresiasi mesin dan kendaraan. Dalam menghitung biaya overhead pabrik, perusahaan hanya memasukkan biaya bahan penolong; Terdapat selisih harga jual antara perhitungan UD. Mutia Meubel dengan penulis yang menggunakan metode full costing, yaitu sebesar $R p$ 151.310,- untuk produk lemari pakaian 2 pintu dan $R p$ 131.720,- untuk produk rak buku.
\end{abstract}

Keywords : perhitungan harga pokok, full costing

\section{PENDAHULUAN}

Perkembangan dunia bisnis di Indonesia sangatlah pesat dan menyebabkan perusahaan yang satu dengan perusahaan yang lain saling bersaing untuk meningkatkan kualitas dan kuantitas perusahaan. Pentingnya usaha industri dalam negeri untuk kegiatan perbaikan perekonomian nasional, mengelola sumber daya yang ada, sehingga pembinaan dan pengembangan terhadap industri kecil dan menengah terus ditingkatkan. Hal ini disebabkan sektor ini mempunyai misi pemerataan serta ikut membantu pemerintah guna dapat memecahkan masalah kerja.

Dalam kondisi ini perusahaan harus berusaha mengikuti perkembangan agar dapat mempertahankan kelangsungan hidup perusahaan dengan memperoleh laba atau keuntungan maksimal. Kegiatan yang berkaitan dengan keuangan merupakan hal penting untuk menjalankan kegiatan operasional perusahaan dalam mengambil keputusan. Penentuan harga pokok produksi merupakan hal yang sangat penting mengingat manfaat informasi harga pokok produksi adalah untuk menentukan harga jual produk, pemantauan realisasi biaya produksi, perhitungan laba rugi periodik serta penentuan harga pokok persediaan produk jadi dan produk dalam proses yang akan disajikan dalam neraca. Dalam memperhitungkan unsur-unsur biaya kedalam harga pokok produksi, terdapat dua pendekatan yaitu full costing dan variable costing.

Kesalahan dalam perhitungan harga pokok produksi dapat mengakibatkan kekeliruan dalam penentuan harga jual produk tersebut yaitu mungkin harga jual menjadi terlalu tinggi ataupun terlalu rendah. Apabila perhitungan harga pokok produksinya kurang tepat dalam perhitungannya, maka yang akan terjadi adalah hasil produk tidak diminati dan akan sulit bersaing dengan produk sejenis yang ada dipasaran. Sebaliknya apabila biaya yang dikeluarkan terlalu tinggi sedangkan pendapatan yang diterima tidak sesuai dengan biaya yang dikeluarkan, hal ini menyebabkan hasil penjualan tidak dapat menutup biaya produksi. 
Apabila keadaan ini terus berlanjut, maka dapat menyebabkan kerugian pada perusahaan.

Perusahaan yang penulis teliti adalah perusahaan yang bergerak dibidang manufaktur khususnya interior, yaitu memproduksi furniture rumah tangga seperti kursi, meja dan lemari yang terbuat dari kayu. Pada kenyataannya pemilik usaha tersebut selama ini menetapkan harga pokok produksi berdasarkan kebijakannya, yaitu penentuan harga jual berdasarkan harga dipasaran dan tidak membebankan biaya listrik dan depresiasi sebagai biaya overhead pabrik. Karena pemilik usaha menargetkan bahwa setiap tahun mendapatkan laba yang sama, sedangkan pada prakteknya biaya yang dikeluarkan tidak sesuai dari tahun ke tahun,

\section{KAJIAN LITERATUR / METODOLOGI /PERANCANGAN}

\subsection{Biaya}

Biaya dalam suatu perusahaan merupakan suatu komponen yang sangat penting dalam menunjang pelaksanaan kegiatan dalam usaha mencapai tujuan. Tujuan itu dapat tercapai apabila biaya yang dikeluarkan sebagai bentuk suatupengorbanan oleh perusahaan yang bersangkutan telah diperhitungkan secara tepat. Pengertian biaya dalam arti luas, "Biaya adalah pengorbanan sumber ekonomi, yang diukur dalam satuan uang, yang telah terjadi atau yang kemungkinan akan terjadi untuk tujuan tertentu. ${ }^{[1]}$

Dalam akuntansi biaya, biaya digolongkan dengan berbagai kriteria. Umumnya penggolongan biaya ini ditentukan atas dasar tujuan yang hendak dicapai dengan penggolongan tersebut, ada lima cara penggolongan biaya yaitu:

1. Penggolongan biaya menurut objek pengeluaran.

2. Penggolongan biaya menurut fungsi pokok dalam perusahaan

3. Penggolongan biaya menurut hubungan biaya dengan sesuatu yang dibiayainya.

4. Penggolongan biaya menurut perilakunya dalam hubungannya dengan perubahan volume kegiatan.

5. Penggolongan biaya atas dasar jangka waktu manfaatnya.

\subsection{Harga Pokok Produksi}

Untuk sebuah perusahaan dagang, jasa, dan industri. Kalkulasi perhitungan harga pokok merupakan suatu hal yang sangat penting, oleh sebab itu harga pokok tersebut hendaknya disusun secara tepat dan rasional dalam arti kata bahwa biaya yang dibebankan sebagai harga pokok dapat menjukkan hal yang wajar, atau dengan kata lain bahwa unsur - unsur harga pokok itu sendiri dapat dialokasikan sesuai dengan fungsi masing masing. Defenisi lain harga pokok adalah "Harga pokok adalah cara memperhitungkan unsur unsur biaya kedalam harga pokok produksi". ${ }^{[1]}$

Terdapat tiga unsur - unsur harga pokok produksi yaitu : biaya bahan baku, biaya tenaga kerja langsung, dan biaya overhead pabrik.

\subsection{Harga Jual}

Harga jual adalah sejumlah kompensasi (uang ataupun barang) yang dibutuhkan untuk mendapatkan sejumlah kombinasi barang atau jasa. Perusahaan selalu menetapkan harga produknya dengan harapan produk tersebut laku terjual dan memperoleh laba yang maksimal. ${ }^{[8]}$ Jadi menurut perusahaan penetapan harga jual adalah suatu keputusan atau strategi perusahaan dalam menarik minat konsumen dan mempertahankan loyalitas pelanggan. "Harga jual adalah jumlah moneter yang dibebankan oleh suatu unit usaha kepada pembeli atau pelanggan atas barang atau jasa atau diserahkan." ${ }^{[2]}$

Dalam menetapkan harga pada sebuah produk perusahaan mengikuti prosedur enam langkah, yaitu:

1. Perusahaan dengan hati-hati menyusun tujuan-tujuan pemasarannya, misalnya mempertahankan hidup, meningkatkan laba saat itu, ingin memenangkan bagian pasar atau kualitas produk.

2. Perusahaan menentukan kurva permintaan yang memperlihatkan keungkinan jumlah produk yang akan terjual per periode, pada tingkat-tingkat harga alternative. Permintaan yang semakin tidak elastic, semakin tinggi pula harga yang dapat ditetapkan perusahaan. 
3. Perusahaan memperkirakan bagaimana biaya akan bervariasi pada tingkat produksi yang berbeda-beda.

4. Perusahaan mengamati harga-harga pesaing sebagai dasar untuk menetapkan harga mereka sendiri.

5. Perusahaan memilih salah satu metode penerapan harga.

6. Perusahaan memilih harga final, menyatakannya dalam cara psikologis yang efektif dan mengeceknya untuk meyakinkan bahwa harga tersebut sesuai dengan kebijakan penetapan harga perusahaan serta sesuai pula dengan para penyalur grosir, wiraniaga perusahaan, pesaing, pemasok, dan pemerintah.

\subsection{Metode Penentuan Harga Pokok Produksi}

Metode penentuan harga pokok produksi adalah cara memperhitungkan unsur-unsur biaya ke dalam harga pokok produksi. Dalam perhitungan unsur-unsur biaya ke dalam harga pokok produksi. Dalam memperhitungkan unsurunsur biaya ke dalam harga pokok produksi, terdapat dua pendekatan : full costing dan variable costing.

Pada umumnya dalam menentukan harga pokok produksi dilakukan dengan memakai metode full costing. Namun juga ada pula dengan mempertimbangkan hal-hal teknis seperti untuk tujuan pengambilan keputusan, maka yang dipakai adalah metode variable costing. Perbedaan pokok metode full costing dan metode variable costing ialah terletak pada perlakuan biaya overhead pabrik. Pada metode full costing, semua biaya produksi baik yang sifatnya tetap maupun yang bersifat variable dianggap bagian dari harga pokok produksi. Sedangkan pada metode variable costing biaya overhead pabrik diperlukan periode biaya dan tidak merupakan bagian dari harga barang dalam proses dan harga pokok barang yang diproduksi.

\subsection{Metode Harga Pokok Pesanan (Job Order Cost System).}

Metode harga pokok pesanan adalah cara pengumpulan harga pokok produksi di mana biaya-biaya produksi dikumpulkan untuk sejumlah produk tertentu, atau suatu jasa yang dapat dipisahkan identitasnya dan yang perlu ditentukan harga pokoknya secara individual. Metode ini tepat digunakan bila produksinya berdasarkan pesanan dari luar atau dari dalam perusahaan.

\subsection{Metode harga pokok proses (Process cost systems)}

Metode ini digunakan untuk barang-barang yang diproduksi melalui cara pengolahan yang berkesinambungan atau melalui proses produksi massal ketika unit-unit bahan yang dikerjakan tidak dapat dibedakan satu sama lain selama satu proses pabrikasi atau lebih. Oleh karena sifat dari outputnya, biaya per unit harus dihitung tiap proses.

\section{METODE PENELITIAN}

\subsection{Jenis Data}

Jenis data yang digunakan dalam penelitian ini yaitu data kuantitatif (data yang dinyatakan dalam bentuk berupa angka-angka) laporan harga pokok produksi 2016-2017. Selain itu, di kumpulkan juga data kualitatif (data yang tidak dinyatakan dalam bentuk angka) yaitu berupa sejarah perusahaan, struktur organisasi perusahaan dan kebijakan akuntansi yang diberlakukan dalam perusahaan serta informasi yang dibutuhkan untuk mendukung penelitian ini.

\subsection{Metode Analisis}

Dalam melakukan penelitian ini metode analisis data yang digunakan adalah :

1. Metode Deskriptif Kualitatif

Metode penelitian yang digunakan adalah metode kualitatif, dimana proses penelitian tersebut memperhatikan konteks studi dengan menitikberatkan pada pemahaman, pemikiran, dan persepsi peneliti. 
2. Metode Deskriptif Kuantitatif

Suatu analisis data dengan merekomendasikan penyusunan harga produksi yang seharusnya dimana metode dinyatakan dengan angka angka. Metode deskripsi kuantitaif yang diperlukan dalam penulisan metode ini adalah : dengan menghitung harga pokok produksi dengan metode yang digunakan perusahaan yaitu dengan metode yang sangat sederhana dimana dalam metode ini biaya bahan, biaya tenaga kerja dan biaya overhead pabrik dikumpulkan perusahaan dengan metode harga pokok pesanan.

Metode harga pokok pesanan adalah suatu metode pengumpulan biaya produksi untuk menentukan harga pokok produksi pada perusahaan atas dasar pesanan. Metode analisa yang digunakan untuk menghitung harga pokok produksi dalam penelitian yaitu metode Full Costing dan Variable Costing.

Rumus metode full costing adalah :

$\sum \mathrm{VC}+\mathrm{FC}$

sedangkan

Rumus metode variable costing adalah :

$\sum \mathrm{VC}$

Pada metode full costing perhitungan untuk biaya bahan baku disatukan sedangkan pada metode variable costing perhitungan biaya bahan bakunya diuraikan berdasarkan masing-masing bahan bakunya.

\section{HASIL DAN PEMBAHASAN}

\subsection{Analisis Penelitian}

Penelitian dilakukan di UD. Mutia Meubel yang sudah berdiri sejak tahun 2013, yang memproduksi furniture rumah tangga yang terbuat dari bahan dasar kayu dalam bentuk lemari hias, lemari pakaian, rak buku, kursi teras, kursi tamu, pintu, jendela, meja, tempat tidur yang terdiri dari berbagai bentuk, contohnya tempat tidur susun dan kursi berbagai bentuk. Usaha ini menerima pesanan barang sesuai permintaan para pelanggan dan desain yang mereka pilih.

UD. Mutia Meubel yang karyawan usahanya dalam melaksanakan kegiatannya dibagi menjadi 3 bagian, yaitu Pekerja A - Bagian Dasar, Pekerja B - Bagian Setengan Jadi dan Pekerja C Bagian Finishing. Jumlah tenaga kerja pada perusahaan mebel seluruhnya berjumlah 6 orang.

Perusahaan menerima pesanan dari konsumen dengan cara menelpon atau datang sendiri ke perusahaan. Proses produksi secara terputus-putus, setelah satu produk selesai dikerjakan barulah dikerjakan produk pesanan lainnya. Dalam setahun perusahaan memiliki kapasitas 180 produk atau \pm 15 produk per bulannya.

\subsection{Unsur - unsur Harga Pokok Produksi UD. Mutia Meubel}

Berdasarkan data yang diperoleh, akan diklasifikasikan unsur-unsur harga pokok produksi yang ada pada usaha UD. Mutia Meubel dengan menggunakan metode full costing untuk menganalisa harga pokok produksi. UD. Mutia Meubel mengklasifikasikan biaya produksi yang dipakai dalam pembuatan lemari pakaian 2 pintu dan rak buku adalah sebagai berikut :

1. Biaya Bahan

2. Biaya Tenaga Kerja

3. Biaya Overhead Pabrik

\subsection{Perhitungan Harga Pokok Produksi dan Harga Jual UD. Mutia Meubel}

Pada UD. Mutia Meubel, perhitungan harga pokok produksi dalam pembuatan 1 buah lemari pakaian 2 pintu dan rak buku 5 susun hanya membebankan biaya bahan baku seperti kayu, biaya tenaga kerja dan bahan penolong. Perhitungan yang dilakukan oleh usaha ini belum memasukkan biaya overhead pabrik seperti biaya listrik, biaya telepon dan biaya depresiasi mesin \& kendaraan.

Harga jual ditetapkan oleh usaha setelah memperhitungkan harga pokok produksi yang dikeluarkan dan ditambah dengan laba yang diinginkan usaha, maka usaha menargetkan harga jual 1 buah lemari pakaian senilai Rp 4.075.000,- 
dan 1 buah rak senilai Rp 3.470.000,-. Usaha ini mempekerjakan 6 karyawan dengan upah harian/jam. Dalam sebulan usaha ini mampu mengerjakan 4 buah lemari pakaian dan sebuah rak buku untuk dijual.

1. Spesifikasi Pesanan

Nama Pesanan 001: Lemari pakaian 2 pintu Jumlah

$$
\text { : } 4 \text { Buah }
$$

Nama Pesanan 002: Rak buku 5 susun

Jumlah : 1 Buah

2. Biaya Bahan Baku Untuk Lemari Pakaian 2 Pintu dan Rak Buku

Tabel 1. Biaya bahan UD. Mutia Mebel

\begin{tabular}{|c|c|c|c|c|}
\hline Produk & Jenis bahan baku & Qty & Harga/unit & Jumlah. \\
\hline Lemari & Kaxu Besi & 32 & $\mathrm{BR} \quad 155,000$ & $B R \quad 4,960,000$ \\
\hline Bak Buku & Kavu linggua & 5 & BR $\quad 130,000$ & 650,000 \\
\hline \multicolumn{4}{|c|}{ Total Biava Bahan Baku } & BR $\quad 5,610,000$ \\
\hline
\end{tabular}

Sumber data : UD. Mutia Mebel

\section{Biaya Tenaga Kerja}

Pada UD. Mutia Meubel, tenaga kerja langsung yang bekerja pada bagian produksi atas permintaan pesanan lemari sebanyak 4 buah dan rak buku terbagi menjadi tiga, yaitu bagian dasar sebanyak 2 orang, bagian setengah jadi sebanyak 2 orang, dan bagian finishing sebanyak 2 orang. Sistem pengupahan didasarkan pada upah harian dan dalam 1 bulan para pekerja bekerja selama 26 hari dengan jam kerja selama 8 jam/hari. Adapun perhitungan biaya tenaga kerja langsung pada UD. Mutia Mebel sebagai berikut :

Tabel 2. Data Perincian Biaya Tenaga Kerja Langsung

\begin{tabular}{|c|c|c|c|c|c|c|c|}
\hline \multirow{2}{*}{ Ketexangan } & \multirow{2}{*}{$\begin{array}{l}\text { Jumlah } \\
\text { Rekeria }\end{array}$} & \multicolumn{2}{|c|}{ Jam Keria } & \multirow{2}{*}{\multicolumn{2}{|c|}{$\begin{array}{c}\text { Jpab Tenaga } \\
\text { Kerja/Jam (RP) }\end{array}$}} & \multicolumn{2}{|c|}{ Jumlah Upah Tenaga Keria } \\
\hline & & Lemari & $\begin{array}{l}\text { Rak } \\
\text { buku }\end{array}$ & & & Lemaxi & Rak bukn \\
\hline Bag. Dasar & 2 Orang & 120 & 20 & $\mathrm{Bn}$ & 20,000 & $\mathrm{Bg} \quad 2,400,000$ & $\mathrm{Bg} \quad 400,000$ \\
\hline Baz. Setengah Jadi & 2 Orang & 80 & 12 & $\mathrm{R}_{n}$ & 15,000 & $R_{n} \quad 1,200,000$ & $\begin{array}{ll}R_{n} & 180,000 \\
\end{array}$ \\
\hline Bag. Finishing & 2 Orang & 40 & 8 & $\mathrm{Rn}$ & 10,000 & $\mathrm{Bn} \quad 400,000$ & 30,000 \\
\hline & tal BTKL & & & $\mathrm{Rn}$ & 45,000 & $\mathrm{Rn} \quad 4,000,000$ & $\mathrm{Bn} \quad 660.000$ \\
\hline
\end{tabular}

\section{Biaya Bahan Penolong}

Berikut ini adalah data biaya bahan penolong yang didapat dari UD. Mutia Meubel sebagai berikut :
Tabel 3. Daftar Biaya Bahan Penolong

\begin{tabular}{|c|c|c|c|c|c|c|c|}
\hline \multicolumn{2}{|c|}{ Produk Pesanan } & \multicolumn{3}{|c|}{ Lemari Pakaian 2 Pintu } & \multicolumn{3}{|c|}{ Rak Buku 5 Susun } \\
\hline Keterangan & Satuan & Qty & Harga & Jumlah & Qty & Harga & Jumlah \\
\hline Amplas & Lembar & 8 & $\begin{array}{l}\mathrm{Rp} \\
40,000\end{array}$ & $\begin{array}{l}\mathrm{Rp} \\
320,000\end{array}$ & 3 & $\operatorname{Rg} 40,000$ & $\begin{array}{l}\mathrm{Rp} \\
120,000\end{array}$ \\
\hline Dempul & $\mathrm{Kg}$ & 4 & $\begin{array}{l}R p \\
35,000 \\
\end{array}$ & $\begin{array}{l}\mathrm{Rp} \\
140,000\end{array}$ & 2 & $\operatorname{Rp} 35,000$ & $\begin{array}{l}\text { Rp } \\
70,000\end{array}$ \\
\hline Cat & Kaleng & 4 & $\begin{array}{l}R p \\
75,000 \\
\end{array}$ & $\begin{array}{l}\mathrm{Rp} \\
300,000\end{array}$ & 1 & $\operatorname{Rp} 75,000$ & $\begin{array}{c}\mathrm{Rp} \\
75,000\end{array}$ \\
\hline Tinnex & Liter & 6 & $\begin{array}{c}\mathbf{R p} \\
21,000\end{array}$ & $\begin{array}{l}\mathrm{Rp} \\
126,000\end{array}$ & 1 & $\operatorname{Rp} 21,000$ & $\begin{array}{c}\mathrm{Rp} \\
21,000\end{array}$ \\
\hline Lem & Kaleng & 4 & $\begin{array}{l}\mathrm{Rp} \\
12,000\end{array}$ & $\begin{array}{l}\mathrm{Rp} \\
48,000\end{array}$ & 1 & Rp. 12,000 & $\begin{array}{l}\mathrm{Rp} \\
12,000\end{array}$ \\
\hline Daku & $\mathrm{Kg}$ & 2 & $\begin{array}{l}R p \\
15,000\end{array}$ & $\begin{array}{l}\text { Rp } \\
30,000\end{array}$ & 1 & $\operatorname{Rp} 15,000$ & $\begin{array}{c}\mathrm{Rp} \\
15,000\end{array}$ \\
\hline Engsel & Pasang & 32 & $\begin{array}{c}\mathrm{Rp} \\
15,000\end{array}$ & $\begin{array}{l}\mathrm{Rp} \\
480,000\end{array}$ & 5 & $\operatorname{Rp} 15,000$ & $\begin{array}{c}\text { Rp. } \\
75,000\end{array}$ \\
\hline Kunci & Buah & 8 & $\begin{array}{c}\text { Rp } \\
25,000 \\
\end{array}$ & $\begin{array}{l}\mathrm{Rp} \\
200,000\end{array}$ & 2 & $\operatorname{Rp}, 25,000$ & $\begin{array}{c}\text { Rp } \\
50,000\end{array}$ \\
\hline $\begin{array}{l}\text { Handle } \\
\text { Bintu }\end{array}$ & Buah & 8 & \begin{tabular}{|l}
$R p$ \\
14,000
\end{tabular} & $\begin{array}{l}\mathrm{Rp} \\
112,000\end{array}$ & 0 & $\mathrm{Rp}$ & $\operatorname{Rp}$ \\
\hline Clear & Kaleng & 4 & $\begin{array}{l}\mathrm{Rp} \\
65,000 \\
\end{array}$ & $\begin{array}{l}\mathrm{Rp} \\
260,000\end{array}$ & 2 & Rp. 65,000 & $\begin{array}{l}\text { Rp } \\
130,000\end{array}$ \\
\hline Total Biaya B & ahan Peno & long & & $\begin{array}{l}\mathrm{Rp} \\
2,016,000\end{array}$ & & & $\begin{array}{l}R p \\
568,000\end{array}$ \\
\hline
\end{tabular}

5. Perhitungan Harga Pokok Produksi UD. Mutia Meubel

Tabel 4. Perhitungan Harga Pokok Produksi

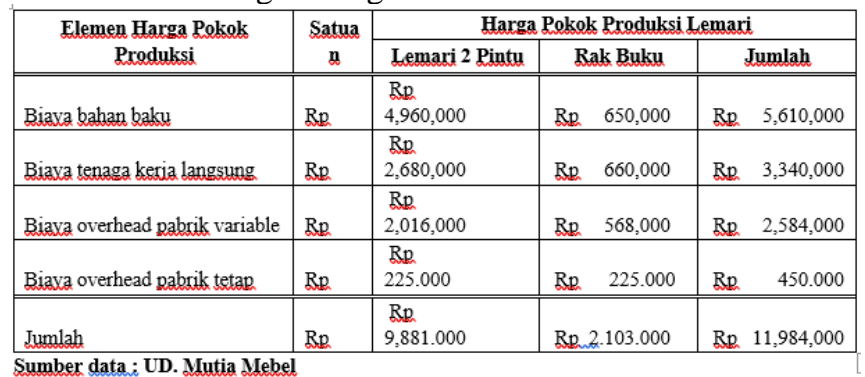

Dengan demikian harga pokok produksi untuk lemari 2 pintu adalah :

Harga pokok produksi per/unit $=\operatorname{Rp} 9,881.000 / 4$ unit $=\operatorname{Rp} 2.470 .250 /$ unit

Pesanan $001=2.470 .250 /$ unit

Pesanan $002=2.103 .000 /$ unit

\section{Penjurnalan}

Pemakaian bahan baku.

$$
\begin{aligned}
& \text { BDP-Biaya bahan baku } \quad \text { Rp } 5610000 \\
& \text { Persediaan bahan baku } \quad \text { Rp } 5,610.000
\end{aligned}
$$

Pemakaian bahan penolong.

Distribusi gaji dan upah: 


\section{Pembebanan BOP :}

Menutup BOP dibebankan ke BOP sesungguhnyai

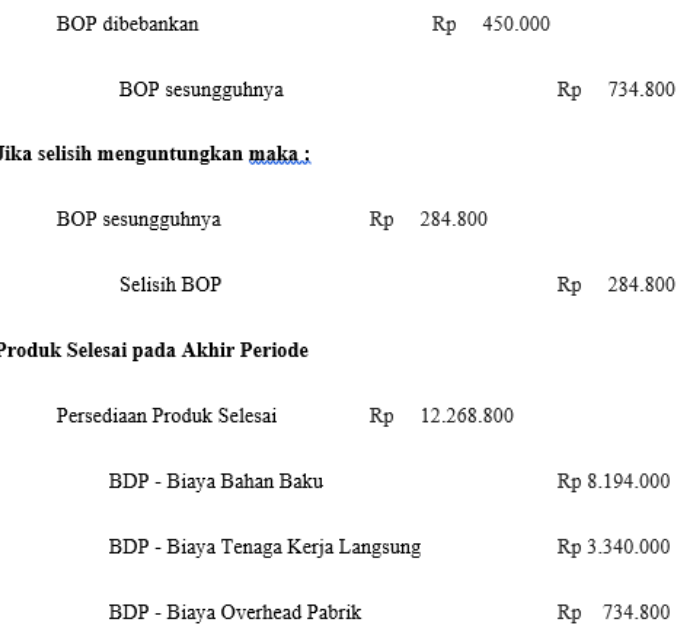

\section{Perhitungan Harga Jual UD. Mutia Meubel}

Dalam menentukan harga jual, perusahaan menginginkan keuntungan sebesar $65 \%$ dari biaya produksi yang dikeluarkan. Perhitungan harga jual sebagai berikut :

Pesanan $001 \quad$ : Lemari Pakaian 2 Pintu

\begin{tabular}{|c|c|c|c|}
\hline Harga pokok produksi & $\mathrm{Rp}$ & 2881t000- & \\
\hline Laba yang diinginkan $65 \%$ & $\underline{\mathrm{Rp}}$ & 6422.650 & \\
\hline Harga jual & & $\mathrm{Rp}$ & 16.303.650 - \\
\hline Harga jual/unit $=\operatorname{Rp} 16.303 .650 / 4$ uni & & $\mathrm{Rp}$ & $4.075 .000,-$ \\
\hline
\end{tabular}

Pesanan 002 : Rak Buku 5 Susun

\begin{tabular}{|c|c|c|}
\hline Harga pokok produksi & $\mathrm{Rp}$ & $2103000=$ \\
\hline Laba yang diinginkan $65 \%$ & $\underline{R p}$ & $1.366 .950=$ \\
\hline Harga jual/unit & $\mathrm{Rp}$ & 3.4700000 \\
\hline
\end{tabular}

$\overline{\text { Sumber data }: \text { UD. Mutia Mebel }}$

Dengan demikian harga jual per/unit lemari 2 pintu sebesar Rp 4.075.000 dan harga jual per/unit rak buku sebesar Rp 3.470 .000

\section{Penyerahan produk selesai kepada pemesan}

\begin{tabular}{|c|c|c|c|c|}
\hline Kas & $\mathrm{Rp}$ & 20.243 .520 & & \\
\hline Penjualan & & & $\mathrm{Rp}$ & 20.243 .520 \\
\hline Harga Pokok Penjualan & $\mathrm{Rp}$ & 12.268 .800 & & \\
\hline Persediaan Produ & elesai & & $\mathrm{Rp}$ & 12.268 .800 \\
\hline
\end{tabular}

\subsection{Perhitungan Harga Pokok Produksi Menggunakan Metode Full Costing}

UD. Mutia Meubel memiliki beberapa peralatan mesin yang digunakan untuk memproduksi produk yang sedang dikerjakan dan sebuah mobil untuk pengantaran. Berikut perhitungan biaya depresiasi sebagai berikut :

Tabel 5. Daftar Biaya Depresiasi UD. Mutia Meubel

\begin{tabular}{|c|c|c|c|c|c|}
\hline Keterangan & Harga Perolehan & $\begin{array}{r}\mathrm{U} \\
\text { Eke }\end{array}$ & $\begin{array}{l}\text { aur } \\
\text { omis }\end{array}$ & & Jumlah \\
\hline Mesin Bor & $\begin{array}{l}\mathrm{Rp}_{2,200,000} \\
2,20\end{array}$ & 5 & Tahun & $\mathrm{Rp}$ & 440,000 \\
\hline Amplas mesin & $\begin{array}{l}\mathrm{Rp} \\
1,200,000\end{array}$ & 5 & Tahun & $\mathrm{Rp}$ & 240,000 \\
\hline Gergaii mesin & $\begin{array}{l}\mathrm{Rp}_{3,200,000}\end{array}$ & 5 & Tahun & $\mathrm{Rp}$ & 640,000 \\
\hline Mesin serut & $\begin{array}{l}\text { Rp } \\
6,200,000\end{array}$ & 5 & Tahun & $\mathrm{Rp}$ & $1,240,000$ \\
\hline Mesin profit & $\begin{array}{l}\mathrm{Rp} \\
4,200,000\end{array}$ & 5 & Tahun & $\mathrm{Rp}$ & 840,000 \\
\hline \multicolumn{4}{|c|}{ Total biaxa depresiasi mesin/tahun } & $\mathrm{Rp}$ & $3,400,000$ \\
\hline
\end{tabular}

\begin{tabular}{|c|c|c|c|}
\hline Keterangan & Harga Perolehan & $\begin{array}{c}\text { Umur } \\
\text { Ekonomis }\end{array}$ & Jumlah \\
\hline $\begin{array}{l}\text { Mobil Daihatsu } \\
\text { Grand Max PU }\end{array}$ & Rp $\quad 223,000,000$ & Tahun & Re $222,300,000$ \\
\hline \multicolumn{3}{|c|}{ Total biaya depresiasi kendaraan/tahun } & Rp 22,300000 \\
\hline
\end{tabular}

1. Biaya Overhead Pabrik

Dari penelitian ini penulis akan menghitung harga pokok produksi dengan dasar pembebanan biaya dengan tarif BOP. Dasar pembebanan yang digunakan adalah biaya tenaga kerja langsung, maka tarif BOP dapat dihitung dengan rumus

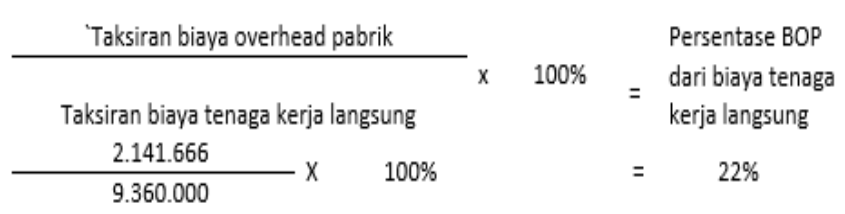




\section{Perhitungan Harga Pokok Produksi}

Penggunaan metode full costing pada penentuan harga pokok produksi dalam perhitungannya terdiri dari biaya bahan baku, biaya tenaga kerja, dan biaya overhead pabrik. Metode full costing dalam proses perhitungannya mencatat seluruh sumber data yang dipakai perusahaan yang memproduksi produknya, sehingga nilai yang dihasilkan lebih akurat dan tepat. Unsur-unsur yang terdapat pada biaya overhead pabrik variabel adalah biaya bahan penolong, biaya listrik, dan biaya telepon. Sedangkan yang terdapat pada biaya overhead pabrik tetap adalah biaya depresiasi.

3. Perhitungan Harga Pokok Produksi Menggunakan Metode Full Costing pada UD. Mutia Meubel

Tabel 6. Perhitungan Harga Pokok Produksi

\begin{tabular}{|c|c|c|c|c|}
\hline \multirow{2}{*}{$\begin{array}{c}\text { Elemen Harga Pokok } \\
\text { Produksi }\end{array}$} & \multirow{2}{*}{ Satuan } & \multicolumn{3}{|c|}{ Harga Pokok Produksi Lemari } \\
\hline & & Lemari 2 Pintu & Rak Buku & Jumlah \\
\hline Biava bahan balad & $\mathrm{RR}$ & $4,4,960,000$ & RR $\quad 650,000$ & $\begin{array}{ll}\mathrm{RR} & 5,610,000\end{array}$ \\
\hline Biava temaga keria langsung & $R R$ & $2,680,000$ & $R B \quad 660,000$ & Rp $\quad 3,340,000$ \\
\hline Biava overhead pabrik tetap & $R R$ & $2,016,000$ & RR. 568,000 & $\mathrm{RR} \quad 2,584,000$ \\
\hline Biava overhead pabrok variabel & $\mathrm{R} R$ & 589,600 & $\operatorname{RR} \quad 145,200$ & $\begin{array}{l}\mathrm{RR} \\
734,800\end{array}$ \\
\hline Jumlah & $\mathrm{RR}$ & $10,245,600$ & RB, 2,023,200 & $\mathrm{RR} \quad 12,268,800$ \\
\hline
\end{tabular}

\section{Penetapan Harga Jual}

Berdasarkan perhitungan harga pokok produksi menggunakan metode full costing, maka ditetapkan harga jual untuk 1 buah lemari pakaian 2 pintu dan rak buku 5 susun adalah :

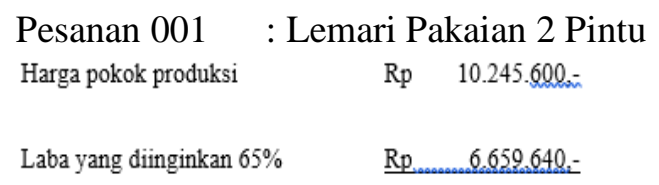

Harga jual yang dibebankan kepada pemesan $\quad R p \quad 16.905 .240$.

Harga jual per $/$ unit $=R p$ 16.905.240- $/ 4$ unit $\quad$ Rp 4.226 .310 ,-
Pesanan 002 : Lemari Pakaian 2 Pintu

\begin{tabular}{|c|c|c|}
\hline Harga pokok produksi & $\mathrm{Rp}$ & $2.023 .200 \mathrm{an}$ \\
\hline Laba yang diinginkan $65 \%$ & $\underline{R p}$ & 1315080 \\
\hline Harga jual per/unit & & 3.338 .280 , \\
\hline
\end{tabular}

Sumber data $;$ Data dilolah, 2018

Tabel 7. Perbandingan Perhitungan Perusahaan dengan Perhitungan Penulis

\begin{tabular}{|c|c|c|}
\hline Keterangan & Lemari Pakaian 2 Pintu & Rak Buku 5 Rak \\
\hline Perusahaan & $\begin{array}{c}\mathrm{Rp} \\
4,075,000 \\
\end{array}$ & $\begin{array}{c}\mathrm{Rp} \\
3,470,000 \\
\end{array}$ \\
\hline Penulis & $\begin{array}{l}\mathrm{Rp} \\
4,226,310\end{array}$ & $\begin{array}{l}\mathrm{Rp} \\
3,338,280\end{array}$ \\
\hline $\begin{array}{l}\text { Selisih perhitungan harga pokok } \\
\text { furniture }\end{array}$ & $\begin{array}{l}\mathrm{Rp} \\
151,310\end{array}$ & $\begin{array}{l}\mathrm{Rp} \\
131,720\end{array}$ \\
\hline
\end{tabular}

Dari tabel perbandingan diatas dapat diketahui bahwa harga jual untuk 1 buah lemari pakaian 2 pintu sebesar Rp 4.226.310,- berbeda dengan harga jual menurut UD. Mutia Meubel sebesar Rp 4.075.000,- sedangkan harga jual untuk 1 buah rak buku 5 susun sebesar Rp 3.470.000,- berbeda dengan harga jual menurut UD. Mutia Meubel sebesar Rp 3.338.280,-.. Maka usaha tersebut selama ini menetapkan harga pokok produksi sesuai dengan perhitungan menggunakan metode full costing yang pada akhirnya berpengaruh pula pada laba yang diperoleh oleh usaha tersebut.

\section{KESIMPULAN}

Dari hasil penelitian dan pembahasan yang telah dilakukan tetang perhitungan Harga Pokok Produksi pada UD. Mutia Meubel, maka dapat ditarik kesimpulan sebagai berikut :

1. UD. Mutia Meubel memperhitungkan harga pokok lemari selama sebulan, perusahaan selama ini hanya membebankan biaya bahan baku, biaya tenaga kerja dan belum membebankan biaya listrik, biaya telepon dan biaya depresiasi sebagai biaya overhead pabrik. Sedangkan pada prinsip akuntansi biaya untuk menghitung harga pokok produk menggunakan metode harga pokok pesanan. 
2. Terdapat perbedaan perhitungan harga pokok produksi antara UD. Mutia Meubel dengan penulis yang menggunakan metode full costing, yaitu harga pokok produksi lemari pakaian 2 pintu menurut perusahaan sebesar $\mathrm{Rp}$ 4.075.000,- dan Rp 3.470.000,- untuk produk rak buku. Sedangkan harga pokok produksi lemari pakaian 2 pintu menurut penulis sebesar Rp 4.226.310,- dan Rp 3.338.280,- untuk produk rak buku. Selisih harga pokok ini disebabkan adanya perbedaan perhitungan biaya overhead pabrik, seperti biaya listrik, biaya telepon dan biaya depresiasi mesin dan kendaraan. Dalam menghitung biaya overhead pabrik, perusahaan hanya memasukkan biaya bahan penolong.

3. Terdapat selisih harga jual antara perhitungan UD. Mutia Meubel dengan penulis yang menggunakan metode full costing, yaitu sebesar Rp 151.310,- untuk produk lemari pakaian 2 pintu dan Rp 131.720,- untuk produk rak buku.

\section{DAFTAR PUSTAKA}

[1] Mulyadi, M.Sc, Drs. 2012. Akuntansi Biaya, Edisi 5. Yogyakarta

[2] Don R. Hansen dan Maryanne M. Mowen. 2000. Akuntansi Manajemen Edisi 4. Yogyakarta
[3] Al Haryono Jusup, M.B.A., AK, Drs. 2011. Dasar-dasar akuntansi, Jilid 2. Yogyakarta: Sekolah Tinggi Ilmu Ekonomi YPKN.

[4] Bastian Bustami dan Nurlela. 2008. Akuntansi Biaya, Edisi 1. Jakarta: Mitra Wacana Media

[5] Mursyidi. 2008. Akuntansi Biaya. Bandung: Refika Aitama

[6] William K. Carter \& Usry, Milton F. 2006. Biaya Edisi 13. Jakarta: Salemba Empat

[7] Supriyono. 2012. Akuntansi Biaya, Edisi 2. Yogyakarta: BPFE

[8] Liawan, Calvin, and VINA VAN HARLING. 2019. "ANALISIS PERLAKUAN AKUNTANSI PENDAPATAN JASA KONSTRUKSI PADA PT. AGRINDO MAKMUR ABADI". SOSCIED 2 (1), 44-51. https://doi.org/10.32531/jsoscied.v2i1.169. 